\title{
STUDI MANAJEMEN PEMELIHARAAN JALAN TOL PADALARANG-CILEUNYI
}

\author{
Maksum Tanubrata $^{[1]}$, Dini Handayani Asmara ${ }^{[2]}$
}

\begin{abstract}
PT. Jasa Marga (Persero) in this time face the condition of where costly turnpike maintenance cost progressively, where as very limited available funds amount. Other side traffic volumes amount which passing turnpike will progressively mount and also claim the existence of adequate service. Hence organizer of turnpike have to look for way to take care of turnpike remain to prima in a condition competent and. To fulfill desire and requirement of society service user of this toll, is needed a way that is system handling of good turnpike. System handling of the turnpike recognized with Management Conservancy of Turnpike or of Maintenance Management System (MMS). This MMS very assist for the agenda of conservancy and management of turnpike of Padalarang-Cileunyi. With existence of MMS entire/ all activity of conservancy, good that conservancy of routine, special and periodic/ emergency, can observe and schedule better. Entire/ All activity of conservancy which have been executed to be to be kept / to be recorded in this MMS, as data which if needed at any times earn is immediately peeped out swiftly. In turnpike organization chart of Padalarang-Cileunyi there are commissioned shares arrange program, execution and also observation of conservancy. Procedures execution of Management Conservancy of Turnpike which there good enough, provided with conservancy procedure, diagram emit a stream of asset data, inspection, and also planning of followup. Pursuant to obtained literature study and data, please get that by using management conservancy of turnpike will facilitate execution of work of conservancy.
\end{abstract}

Keyword: Management Conservancy, Turnpike.

\begin{abstract}
ABSTRAK
PT. Jasa Marga (Persero) saat ini menghadapi kondisi dimana biaya pemeliharaan jalan tol semakin mahal, sementara jumlah dana yang tersedia sangat terbatas. Disisi lain jumlah volume lalu lintas yang melalui jalan tol akan semakin meningkat serta menuntut adanya pelayanan yang memadai. Maka pengelola jalan tol harus mencari cara untuk menjaga agar jalan tol tetap dalam kondisi yang prima dan layak. Untuk memenuhi keinginan dan kebutuhan dari masyarakat pengguna jasa tol ini, diperlukan suatu cara yaitu sistem penanganan jalan tol yang baik. Sistem penanganan jalan tol tersebut dikenal dengan Manajemen Pemeliharaan Jalan Tol atau Maintenance Management System (MMS). MMS ini sangat membantu dalam rangka pemeliharaan dan pengelolaan jalan tol PadalarangCileunyi. Dengan adanya MMS seluruh kegiatan pemeliharaan, baik itu pemeliharaan rutin, periodik dan khusus/darurat, dapat terawasi dan terjadwal dengan baik. Seluruh kegiatan pemeliharaan yang telah dilaksanakan disimpan/direkam dalam MMS ini, sebagai data yang apabila diperlukan sewaktuwaktu dapat segera dimunculkan dengan cepat. Dalam struktur organisasi jalan tol PadalarangCileunyi terdapat bagian yang bertugas mengatur program, pelaksanaan serta pengawasan pemeliharaan. Tata cara pelaksanaan Manajemen Pemeliharaan Jalan Tol yang sudah ada cukup baik, dilengkapi dengan prosedur pemeliharaan, diagram alir pendataan aset, inspeksi, serta perencanaan tindak lanjut. Berdasarkan data dan studi literatur yang diperoleh, didapatkan bahwa dengan menggunakan manajemen pemeliharaan jalan tol akan memudahkan pelaksanaan pekerjaan pemeliharaan.
\end{abstract}

Kata Kunci: Manajemen pemeliharaan, Jalan tol. 


\section{PENDAHULUAN}

\subsection{Latar Belakang}

Pembangunan infrastruktur jalan telah terbukti secara nyata mampu memperlancar arus manusia, barang dan jasa serta beragam informasi ke segala penjuru wilayah. Demikian pula infrastruktur jalan tol di kota Bandung yang merupakan salah satu gerbang masuk bagi masyarakat untuk melakukan segala macam aktifitas menuju atau dari dan melewati kota Bandung.

Pada masa yang akan datang, PT. Jasa Marga sebagai pengelola jalan tol akan dihadapkan pada suatu kondisi dimana biaya pengelolaan jalan menjadi semakin mahal sementara jumlah dana yang tersedia sangat terbatas. Disisi lain jumlah volume lalu lintas yang melalui jalan tol akan semakin meningkat serta menuntut adanya pelayanan yang memadai. Pada saat itulah pengelola jalan tol harus mencari cara terbaik dalam menangani jaringan jalan yang ada sehingga mencapai suatu tingkat pelayanan yang layak dan kendala keterbatasan dana.

Adalah merupakan tanggung jawab pengelola jalan tol untuk menyiapkan anggaran yang lebih ketat dan kriteria pengelolaan yang jelas dalam setiap biaya yang dikeluarkan. Diperlukan metode yang tepat untuk memperkirakan dan mengalokasikan biaya, anggaran, dan sumber daya yang dibutuhkan untuk melaksanakan program pemeliharaan.

Banyak cara untuk mengatur program pemeliharaan dengan anggaran yang terbatas. Salah satu metode yang banyak dipakai saat ini adalah Maintenance Management System (MMS). MMS didefinisikan sebagai proses optimasi kinerja jaringan yang isinya meliputi beberapa aktivitas pemeliharaan jaringan beserta prasarananya.

\subsection{Tujuan}

Tujuan penelitian adalah mempelajari manajemen pemeliharaan jalan tol Padalarang Cileunyi yang sudah ada, sehingga didapatkan manajemen pemeliharaan jalan tol yang baik.

\subsection{Batasan Studi}

Dalam studi ini diambil manajemen pemeliharaan jalan tol Padalarang - Cileunyi yang sudah ada, dengan mempelajari cara pelaksanaan pekerjaan pemeliharaan yang dilakukan apakah sudah memenuhi persyaratan atau prosedurnya. Pembahasan pekerjaan pemeliharaan ini dibatasi hanya pada pemeliharaan periodik pada bulan Juli - Desember 2007, dan tidak dibahas rincian biayanya. 


\section{TINJAUAN PUSTAKA}

\subsection{Jalan Tol}

Undang-Undang nomor 38 tahun 2004 tentang jalan tol, menyebutkan bahwa jalan tol adalah jalan umum yang merupakan bagian dari sistem jaringan jalan dan sebagai jalan nasional yang penggunanya dikenakan kewajiban membayar tol. Sedangkan tol adalah sejumlah uang tertentu yang harus dibayarkan untuk pemakaian jalan tol. Masyarakat yang berhak menggunakan jalan tol adalah masyarakat yang menggunakan kendaraan bermotor roda 4 atau lebih. Tujuan penyelenggaraan jalan tol adalah sebagai berikut:

1. Memperlancar lalu lintas di daerah yang telah berkembang.

2. Meningkatkan hasil guna dan daya guna pelayanan distribusi barang dan jasa guna menunjang peningkatan pertumbuhan ekonomi.

3. Meringankan beban dana Pemerintah melalui partisipasi pengguna jalan

4. Meningkatkan pemerataan hasil pembangunan dan keadilan.

Selain itu tujuan dari pembangunan jalan tol, yaitu:

1. Menjamin kelancaran arus lalu lintas jarak jauh, terutama bagi pengendara komersial dan lalu lintas perkotaan yang lain.

2. Mempunyai fungsi sebagai pengendalian arus lalu lintas wilayah dan mengurangi kejenuhan jaringan jalan di sekitar lokasi akibat meningkatnya volume lalu lintas.

3. Menghemat biaya operasional kendaraan dan waktu tempuh bagi para pemakai jalan.

4. Memenuhi kebutuhan masyarakat akan prasarana jalan, sehubungan dengan semakin meningkatnya laju pertumbuhan dan perkembangan kendaraan.

5. Mengurangi pengaruh-pengaruh negatif akibat tingkat pelayanan yang tidak memadai seperti tingkat kadar polusi, dan jumlah kecelakaan lalu lintas.

6. Meningkatkan kapasitas jalan, karena jalan yang sudah ada tidak mampu lagi menampung volume lalu lintas yang ada.

Dari hal tersebut di atas dapat disimpulkan bahwa jalan tol mempunyai peran untuk melayani jasa distribusi utama yang mempunyai spesifikasi bebas hambatan agar dicapai tingkat efisiensi yang maksimal dalam penggunaan sumber daya, serta sebagai pemacu pengembangan wilayah untuk mewujudkan keseimbangan perkembangan antar daerah.

\subsection{Manajemen Pemeliharaan}

Pengembangan sistem manajemen pemeliharaan ini diawali pada tahun 1983 dengan diadakannya studi Technical Assisten and Training in Toll Road Managemant yang dilaksanakan oleh The New Jersey Turnpike Authority dan Louis Beger pada periode tahun 
1983 - 1985. Hasilnya berupa satu set laporan teknis yang berisi tentang kajian terhadap pengoperasian jalan tol yang dilaksanakan oleh PT. Jasa Marga (Persero). Laporan teknis yang dihasilkan oleh studi ini belum dapat sepenuhnya digunakan sebagai acuan untuk sistem manajemen pemeliharaan jalan tol, mengingat studi tersebut hanya memuat gambaran operasional PT. Jasa Marga dan advis teknis yang diperlukan pada saat itu.

Pada tahun 1989 suatu tim studi dari Jepang yaitu IECA-EHRF-OPMAC, melakukan Studi Management Service for The Tollway System yang substansinya tidak jauh berbeda dengan studi yang dilakukan oleh The New Jersey Turnpike. Pembahasan mengenai Manajemen Pemeliharaan Jalan Tol Hanya terfokus pada dua pokok bahasan yaitu Manual Inspeksi Pekerjaan Pemeliharaan dan Pengukuran \& Evaluasi Kondisi Perkerasan. Meskipun Laporan teknis yang disajikan telah cukup terperinci namun masih terdapat kesulitan dalam menerapkan di lapangan dikarenakan oleh tidak tersedianya petunjuk pelaksanaan pengisian formulir survey maupun tata cara mengevaluasinya.

Pada tahun 1991 dimulai proyek Toll Road Desain, Maintenance Management System tahap 1 (MMS-1). Studi ini dilaksanakan oleh Noadtec Resources (NZ) LTD/PT Virama Karya/Disiplan Consult. Tujuan studi ini adalah membuat standar desain jalan tol, kendali mutu pembangunan dan pemeliharaan jalan tol serta menyusun suatu sistem pemeliharaan jalan tol. Dari studi ini semula diharapkan akan dapat diperoleh suatu strategi yang mencakup penanganan pemeliharaan jalan tol mulai dari perencanaan pemeliharaan sampai dengan penyiapan dokumen tender untuk pekerjaan pemeliharaan. Namun sampai dengan selesainya studi, hasil yang dicapai baru sebatas pada pembuatan pangkalan data.

MMS tahap 2 dilaksanakan oleh lembaga penelitian ITB pada tahun 1994 yang merupakan kelanjutan dari MMS tahap 1. Seperti halnya konsep MMS tahap 1 maka MMS tahap 2 dirancang dengan sistem modular dengan penekanan pada penyelesaian Treatment Policy Module (TPM) dan Economic \& Financial Evoluation Module (EFEM) yang membentuk Planning and Budgeting Module (PBM). Aspek yang dicakup dalam MMS II ini baru mencakup perkerasan jalan tol, belum meliputi 5 aset lain seperti geometrik, jembatan, gedung, peralatan dan elektrikal. Lebih dari itu belum mencakup Design Tendering Module (DTM) dan Contract Implementation Module (CIM) yang merupakan bagian tak terpisahkan dari pengembangan konsep MMS untuk perkerasan jalan tol secara keseluruhan.

Pada tahun 1998 dilakukan penyempurnaan program MMS menjadi suatu sistem manajemen pemeliharaan jalan tol yang lebih terpadu. Program ini disebut sebagai Integrated Maitenance Management System (IMMS) atau lebih dikenal dengan MMS II+. Program MMS II+ merupakan sistem yang terkomputerisasi sebagai alat bantu bagi PT. Jasa 
Marga (Persero) dalam melaksanakan kegiatan pemeliharaan jaringan jalan tol yang meliputi:

1. Menyediakan informasi dalam pangkalan data MMS mengenai karakteristik dan kondisi jaringan jalan tol.

2. Perkiraan anggaran pemeliharaan rutin tahunan.

3. Penyusunan rencana dan anggaran pemeliharaan berkala dan peningkatan lima tahunan.

4. Persiapan dokumen lelang/kontrak pekerjaan pemeliharaan.

5. Pemantauan pelaksanaan pekerjaan pemeliharaan.

6. Pelaporan dan informasi geografis mengenai pemeliharaan jaringan jalan tol.

\subsection{Prosedur Pemeliharaan Fasilitas Operasi}

\subsubsection{Tujuan}

Prosedur ini bertujuan mengatur pelaksanaan kegiatan pemeliharaan fasilitas operasi, sehingga dapat dicapai keseragaman pola tindak lanjut dan tanggung jawab bagi unit bagian Program Pemeliharaan serta unit lain dalam rangka pelaksanaan pemeliharaan fasilitas operasi agar dalam keadaan siap dioperasikan.

\subsubsection{Ruang Lingkup}

Prosedur pemeliharaan fasilitas operasi ini mencakup tata cara pemeliharaan yang meliputi perawatan, rehabilitas/perbaikan, penujangan dan peningkatan yang berdasarkan Rencana Kerja Anggaran Perusahaan (RKAP) dengan aktivitas rutin mulai dari inspeksi, pengumpulan data, evaluasi data, menentukan alternatif penanganan sampai dengan analisis data untuk dituangkan dalam RAB (Rencana Anggaran Biaya) sampai dengan pelaksanaan pekerjaan pemeliharaan di PT. Jasa Marga (Persero).

\subsubsection{Rencana Kerja Anggaran Perusahaan (RKAP)}

1. Penyusunan RKAP Cabang untuk tahun ke depan disiapkan paling lambat bulan ketiga pada triwulan III pada tahun berjalan.

2. RKAP disusun secara detail dengan cerminan program kerja, biaya serta alokasinya, dengan merujuk pada hasil inspeksi dan laporan kerusakan yang masuk pada pangkalan data atau merupakan program yang tertunda.

3. Kepala Cabang manetapkan kebijakan RKAP Cabang bidang pemeliharaan fasilitas operasi. 
4. Kepala Bagian Pemeliharaan harus membuat rencana aktivitas pencapaian tolak ukur pemeliharaan fasilitas operasi yang berdasarkan pada RKAP hasil RUPS dengan mengatur waktu pelaksanaan program-program yang ada pada RKAP secara rinci menurut titik kontrol dan penanggung jawabnya.

5. Kepala Sub Bagian Program Pemeliharaan harus melaksanakan monitoring pelaksanaan rencana aktivitas yang dibuat oleh Kepala Bagian Pemeliharaan.

\subsubsection{Pelaksanaan Inspeksi}

1. Kepala Sub Bagian Program Pemeliharaan harus menyusun jadwal inspeksi dan pendatan aset pemeliharaan secara bulanan, paling lambat bulan ketiga minggu keempat triwulan berjalan sesuai lampiran.

2. Kepala Bagian Pemeliharaan harus memberikan persetujuan jadwal inspeksi dan pendataan aset pemeliharaan.

3. Tata Usaha Pelayanan Umum harus melaksanakan pengetikan dan pendistribusian jadwal inspeksi dan pendataan aset pemeliharaan.

4. Teknisi terkait harus melaksanakan inspeksi sesuai jadwal yang telah ditetapkan dan melaporkan hasil pelaksanaan inspeksi kepada Juru Teknik terkait paling lambat 1 hari setelah pelaksanaan inspeksi.

5. Tata Usaha Pendataan harus melaksanakan pendataan aset pemeliharaan sesuai jadwal yang telah ditetapkan serta merekap hasil pendataan tersebut dan melaporkan kepada Juru Tata Usaha Pengolahan Data Pemeliharaan paling lambat 1 hari setelah pelaksanaan.

6. Juru Teknik terkait menerima laporan hasil inspeksi serta harus memperbarui jadwal hasil pelaksanaan inspeksi.

7. Juru Teknik terkait harus membuat laporan kerusakan dan rencana penanganan kerusakan berdasarkan hasil inspeksi kepada Kepala Sub Bagian Program Pemeliharaan melalui Juru Tata Usaha Pengolahan Data Pemeliharaan.

8. Juru Tata Usaha Pengolahan Data Pemeliharaan manerima laporan hasil pendataan serta harus memperbarui jadwal hasil pelaksanaan pendataan.

9. Tata Usaha Pendataan menerima berkas hasil inspeksi dari Juru Tata Usaha Pengolahan Data Pemeliharaan dan harus membuat rekapitulasi hasil inspeksi tersebut.

10. Kepala Sub Bagian Program Pemeliharaan bersama-sama Juru Tata Usaha Pengolahan Data Pemeliharaan harus membuat laporan performa aset pemeliharaan 
kepada Kepala Bagian Pemeliharaan berdasarkan data laporan hasil inspeksi dan pendataan.

11. Kepala Sub Bagian Program Pemeliharaan harus mengevaluasi laporan performa aset pemeliharaan dengan kategori (R1, R2 dan R3) dan prioritas penanganan (P1 dan P2). Apabila hasil evaluasi ternyata merupakan kategori kerusakan berat (R1) yang tidak dapat ditunda atau prioritas (P1), maka perlu merujuk program pada rencana kegiatan yang telah ditetapkan (action plan), maka mengusulkan penanganan tindak lanjut tersebut kepada Kepala Bagian Pemeliharaan.

12. Kepala Bagian Pemeliharaan harus melakukan evaluasi rencana aktivitas tindak lanjut penanganan yang tidak terdapat pada program yang telah ditetapkan (action plan). Apabila program penanganan tindak lanjut tersebut tidak dapat ditunda, maka Kepala Bagian Pemeliharaan mengusulkan perubahan program atau mutasi anggaran kepada Kepala Cabang.

13. Kepala Cabang memberikan persetujuan usulan perubahan program atau mutasi. Apabila mendapat persetujuan Kepala Cabang, maka program dapat ditindak lanjut dengan perencanaan. Dan apabila tidak disetujui, dimasukan kedalam program yang ditunda.

\subsubsection{Perencanaan Program Tindak Lanjut}

1. Juru Teknik dan Teknisi terkait secara bersama-sama harus melakukan perencanaan tindak lanjut yang telah ditetapkan/mendapatkan persetujuan revisi. Perencanaan tindak lanjut meliputi perhitungan volume, gambar, spesifikasi, analisa terinci harga satuan dan Rencana Anggaran Biaya. Dan mengusulkan kepada Kepala Sub Bagian Program Pemeliharaan melalui Juru Tata Usaha Pengolahan Data Pemeliharaan.

2. Kepala Sub Bagian Program Pemeliharaan harus melakukan pemeriksaan rencana program tindak lanjut.

3. Kepala Bagian Pemeliharaan memberikan persetujuan program tindak lanjut. Dan meminta persetujuan Kepala Cabang yang diwujudkan dalam bentuk Ijin Penggunaan Anggaran (IPA) dan dilengkapi data dukung teknis yang lengkap, melalui Bagian Keuangan.

4. Juru Tata Usaha Pengolahan Data Pemeliharaan dan Tata Usaha pendataan secara bersama-sama harus melakukan pencatatan dan monitoring program kerja dan anggaran. 


\subsubsection{Pengendalian Mutu Pekerjaan}

1. Kepala Bagian Pemeliharaan harus mengeluarkan surat Penugasan Pengendalian Mutu Pekerjaan kepada Kepala Sub Bagian Pengawasan Pengendalian dan Evaluasi Pemeliharaan, Juru serta Teknisi yang ditugaskan untuk melaksanakan pengendalian pekerjaan dari segi volume, waktu dan mutu sesuai ketentuan kontrak.

2. Kepala Sub Bagian Pengawasan Pengendalian dan Evaluasi Pemeliharaan harus memonitor pelaksanaan program tindak lanjut yang dilaporkan oleh Juru dan Teknisi terkait dalam pengendalian mutu pekerjaan setiap minggu pada hari pertama.

3. Proses pemeriksaan pekerjaan dilakukan setelah pekerjaan diselesaikan sesuai volume, spesifikasi, gambar rencana dan waktu pelaksanaan dalam kontrak. Pemeriksaan pekerjaan dilakukan bersama-sama oleh pengendalian mutu pekerjaan dari PT. Jasa Marga dan kontraktor yang dituangkan dalam Berita Acara Pemeriksaan Pekerjan yang ditanda tangani bersama dan diketahui oleh Kepala Bagian Pemeliharaan dan dilengkapi dengan laporan pengendalian mutu pekerjaan.

4. Kepala Sub Bagian Pengawasan Pengendalian dan Evaluasi Pemeliharaan, Juru dan Teknisi terkait harus melakukan penyempurnaan data yang dilaksanakan setiap triwulan sekali dengan cara menghimpun, menyusun dan memperbaharui data pemeliharaan.

\section{PENGUMPULAN DATA}

\subsection{Peta Jalan Tol Padalarang-Cileunyi}

Jalan tol Padalarang-Cileunyi berada di sebelah selatan kota Bandung. Jalan tol ini dimaksudkan agar kendaraan dari arah timur (Cirebon, Tasikmalaya dan Garut) yang menuju ke arah barat (Jakarta) dan sebaliknya tidak melalui jalan dalam kota Bandung, serta memperlancar kendaraan yang akan masuk dan keluar kota Bandung, terutama dari arah selatan, yaitu Soreang, Banjaran dan Majalaya. Jalan tol tersebut dapat dilihat pada Gambar 1 berikut: 


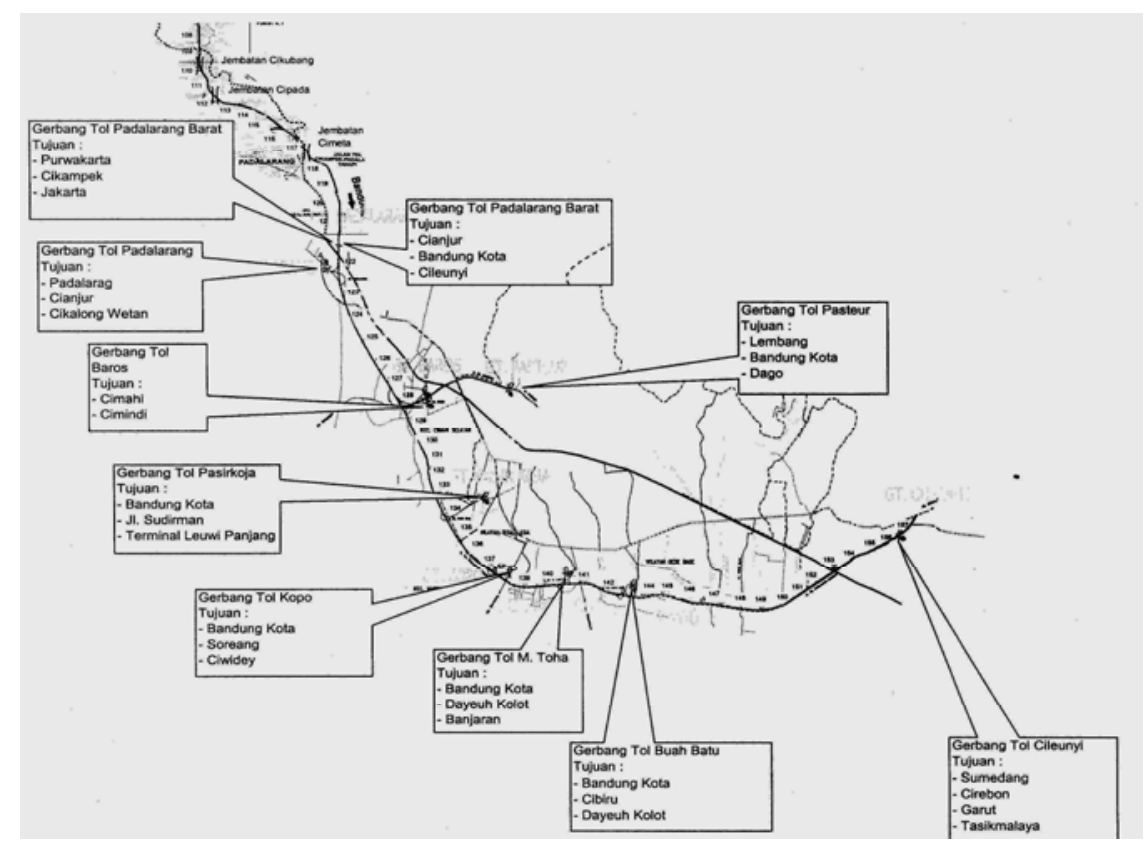

Gambar 1. Peta Jalan Tol Padalarang-Cileunyi.

\subsection{Struktur Organisasi Jalan Tol Padalarang-Cileunyi}

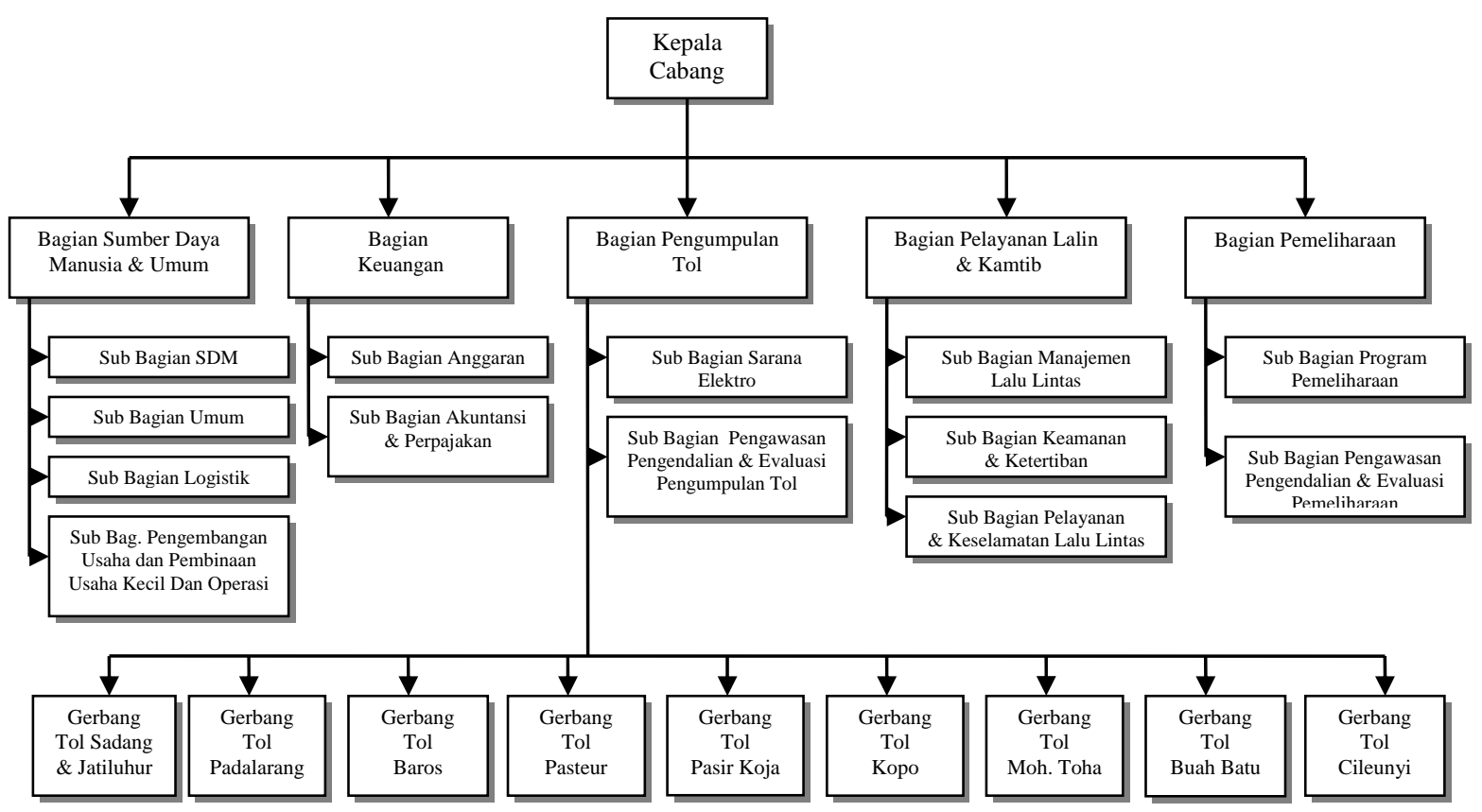

Gambar 2. Srtuktur Organisasi Jalan Tol Padalarang-Cileunyi. 


\subsection{Diagram Alir Pendataan Fasilitas Operasi}

Instruksi kerja pelaksanaan pendataan ini bertujuan untuk menyeragamkan pola tindak lanjut tugas inventarisasi fasilitas operasi dalam rangka mengoptimalkan kegiatan/program pemeliharaan. Langkah-langkahnya dapat dilihat pada gambar berikut ini:

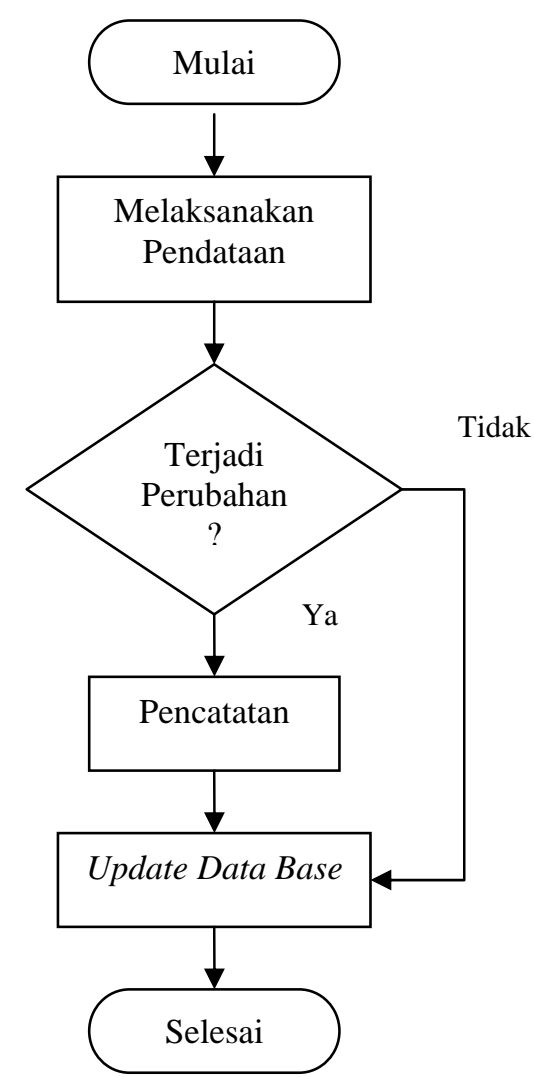

Gambar 3. Diagram alir pendataan fasilitas operasi

\subsection{Diagram Alir Inspeksi Fasilitas Operasi}

Dalam instruksi kerja inspeksi fasilitas operasi ini terdapat diagram alir langkahlangkah pekerjaannya, seperti pada gambar berikut ini: 


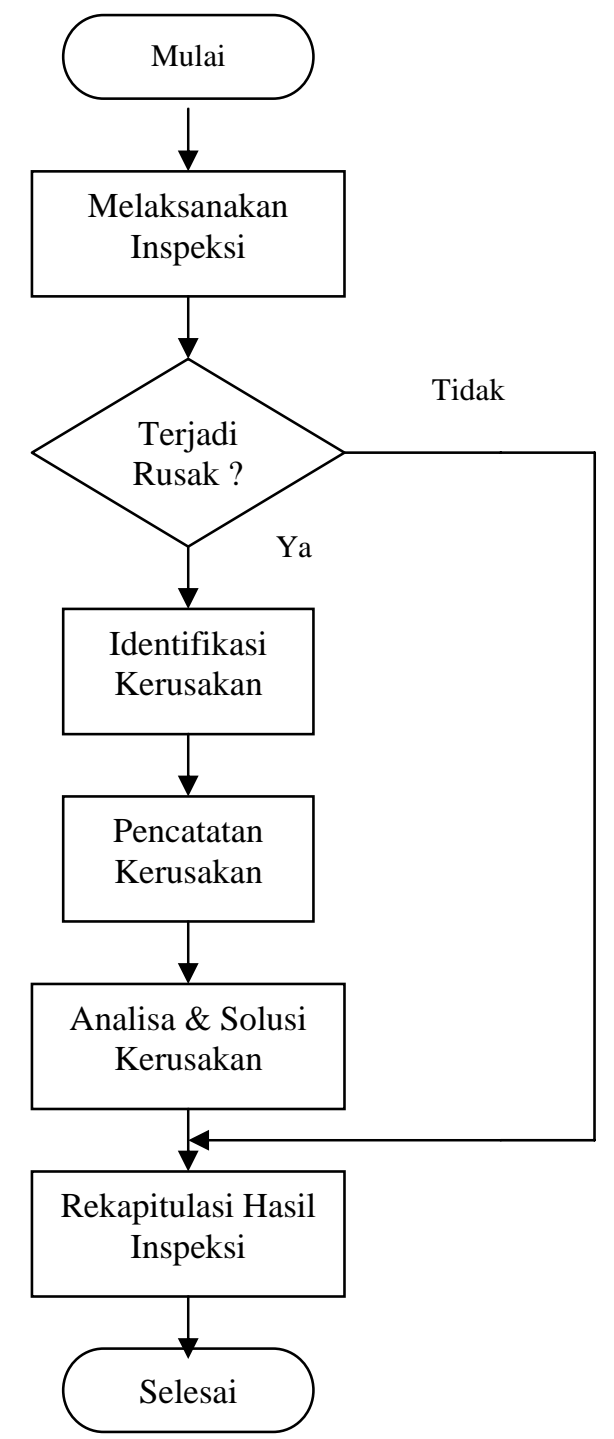

Gambar 4. Diagram alir inspeksi fasilitas operasi

\subsection{Diagram Alir Perencanaan Tindak Lanjut}

Pada gambar dibawah ini dapat dilihat langkah-langkah instruksi kerja perencanaan tindak lanjut dalam bentuk diagram alir, yaitu sebagai berikut: 


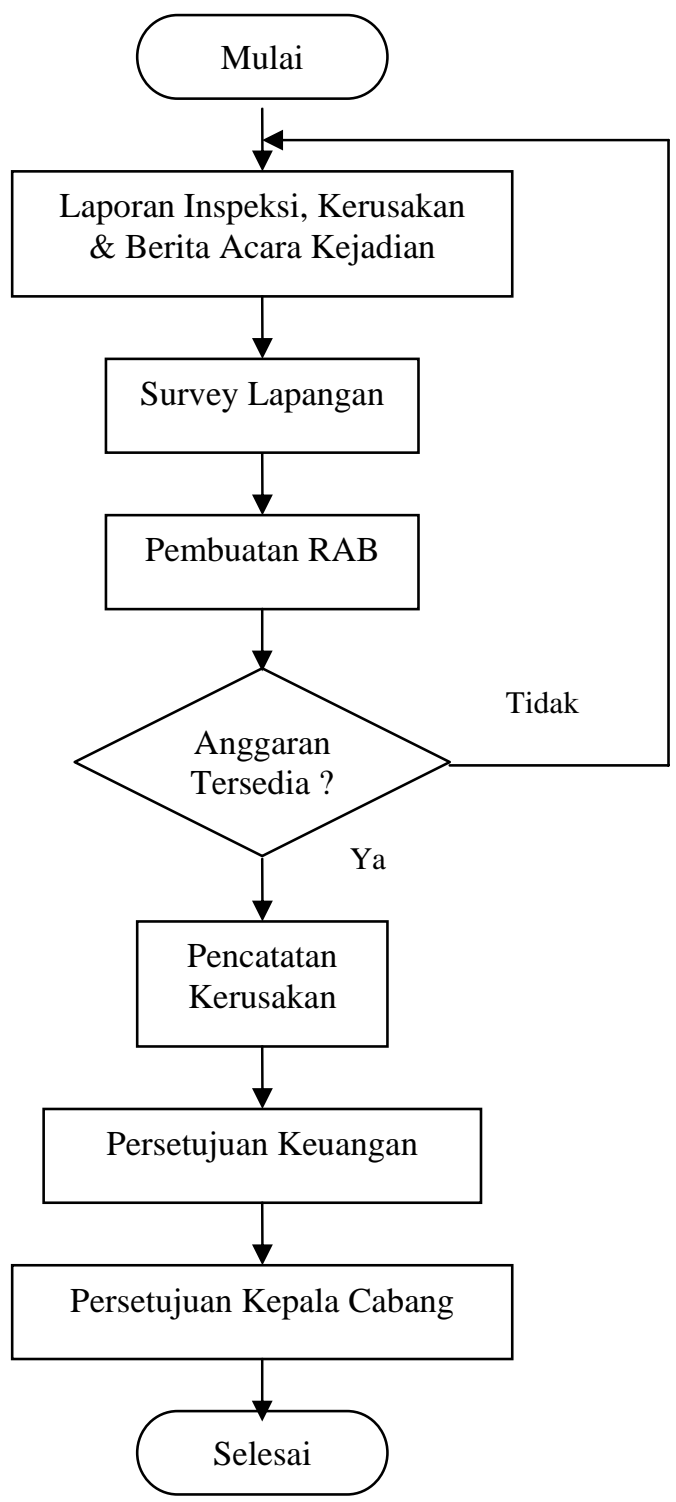

Gambar 5. Diagram alir perencanaan tindak lanjut.

\section{Diagram Alir Pengendalian Mutu Pekerjaan}

Instruksi Kerja Pengendalian Mutu Pekerjaan ini mencakup kegiatan-kegiatan dari mulai menerima surat penugasan pengendalian mutu pekerjaan, penerimaan dokumen kontrak, persiapan pekerjaan, pengawasan pekerjaan, pemeriksaan pekerjaan sampai dengan proses pembuatan Berita Acara Pemeriksaan Pekerjaan, seperti pada gambar berikut ini: 


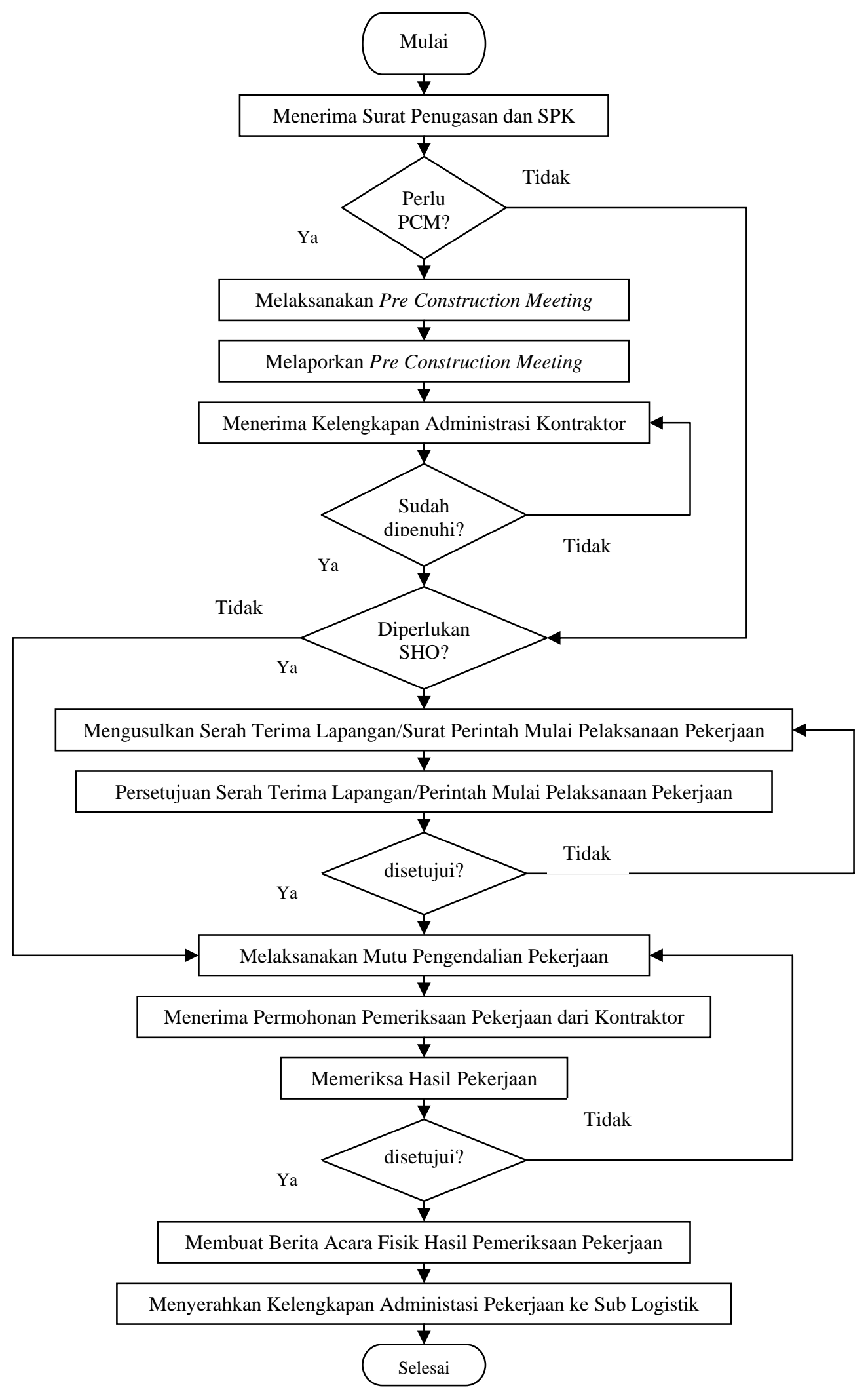

Gambar 6. Diagram alir pengendalian mutu pekerjaan. 


\section{ANALISIS DATA}

\subsection{Analisis Struktur Organisasi Jalan Tol Padalarang-Cileunyi}

Analisis struktur organisasi jalan tol Padalarang-Cileunyi yang dapat dilihat pada Gambar 2, mencakup analisis pada kebijakan serta tugas yang dilaksanakan oleh pihak yang ditugaskan untuk melaksanakan pekerjaan pemeliharaan jalan tol. Analisis struktur organisasi dilakukan karena menyangkut sumber daya manusia yang terkait dalam manajemen pemeliharaan jalan tol sehingga dapat dicapai keseragaman pola tindak lanjut pekerjaan dan tanggung jawab masing - masing.

Pada struktur organisasi jalan tol cabang Padalarang-Cileunyi sebagian besar unsur yang harus dimiliki dalam suatu struktur organisasi sudah ada. Struktur organisasi yang baik dirasakan sangat penting untuk meningkatkan kualitas perusahaan yang semakin lama semakin berkembang. Dalam hal ini, yaitu pada pekerjaan pemeliharaan semua pihak yang terkait pada struktur organisasi dimulai dari tahap pendataan, inspeksi, perencanaan, pelaksanaan dan pengawasan harus menunjukkan koordinasi serta kinerja yang baik dalam menjalankan tugas dan wewenang.

Di sini hanya akan dibahas mengenai bagian pemeliharaannya saja. Pada bagian ini terdiri dari 2 sub bagian, yaitu sub bagian program pemeliharaan dan sub bagian pengawasan pengendalian dan evaluasi pemeliharaan.

Sub bagian program pemeliharaan ini bertugas menyusun program-program pemeliharaan, penyiapan dokumen, serta pengelolaan pemeliharaan. Contohnya yaitu melakukan pendataan fasilitas operasi, membuat laporan hasil inspeksi fasilitas operasi, serta menyusun perencanaan tindak lanjut. Sedangkan pada sub bagian pengawasan pengendalian dan evaluasi pemeliharaan, bertugas mengawasi pelaksanaan pekerjaan pemeliharaan, pengendalikan mutu pekerjaan, serta mengevaluasi hasil pekerjaan pemeliharaan apakah sesuai dengan yang direncanakan. Pada sub bagian ini terdiri dari juru teknik bangunan gedung, jalan dan jembatan, mekanikal elektrikal, teknik lingkungan, sarana pelengkap jalan, dan bangunan pelengkap jalan.

Dari uraian di atas dapat dilihat bahwa semua pihak terkait dalam pekerjaan pemeliharan saling berkoordinasi dan menjalankan tugas serta wewenangnya.

\subsection{Analisis Instruksi Kerja Pendataan Fasilitas Operasi}

Pada pendataan fasilitas operasi, langkah ini sangat penting sekali untuk dapat mengoptimalkan kegiatan/program pemeliharaan. Dengan kata lain bila pada saat pendataan 
terjadi kesalahan pencatatan maka kegiatan pemeliharaan tidak akan mendapat hasil yang maksimal.

Untuk langkah-langkah yang dilakukan dapat dilihat pada Gambar 3, dimulai dari melaksanakan pendataan. Pendataan yang dimaksud adalah melakukan pendataan mengenai jumlah serta kondisi fasilitas jalan tol tersebut. Bila terjadi perubahan, baik itu mengenai jumlah ataupun kondisi fasilitas operasi, Pendata bisa langsung melakukan pencatatan, untuk perubahan kondisi fasilitas operasi tidak perlu dilakukan pemeriksaan kerusakan yang mendetail. Pencatatan ini nantinya akan dipakai untuk mengupdate data base. Baik itu ada perubahan ataupun tidak ada perubahan, Pendata harus tetap mengupdate data base. Data ini nantinya akan dipakai dalam pelaksanaan inspeksi.

\subsection{Analisis Instruksi Kerja Inspeksi Fasilitas Operasi}

Setelah melakukan pendataan fasilitas operasi, kegiatan selanjutnya yaitu inspeksi. Inspektor menginspeksi fasilitas operasi berdasarkan data yang diperoleh dari hasil pendataan. Dari diagram alir inspeksi (Gambar 4), disebutkan bila pada saat pelaksanaan inspeksi, inspektor menemukan adanya kerusakan harus dilakukan identifikasi kerusakan, yang kemudian dilakukan pencatatan mengenai kerusakan tersebut untuk dianalisa, serta dicari solusi yang tepat untuk menangani kerusakan tersebut. Barulah pada akhirnya melakukan rekapitulasi hasil isnpeksi tersebut, untuk diserahkan pada bagian perencana tindak lanjut. Begitu juga bila pada saat inspeksi tidak ditemukan kerusakan pada fasilitas operasi, inspektor tetap harus merekapitulasi hasil inspeksi.

Data hasi inspeksi, yang disertai analisa identifikasi kerusakan dan rencana penanganannya dserahkan kepada Kepala Sub Bagian Program Pemeliharaan untuk dievaluasi. Bila mendapat persetujuan, pekerjaan pemeliharaan dapat dilanjutkan ke tahap berikutnya.

\subsection{Analisis Instruksi Kerja Perencanaan Tindak lanjut}

Pada diagram alir perencanaan tindak lanjut (Gambar 5), disebutkan setelah bagian perencana menerima laporan inspeksi mengenai jenis kerusakan fasilitas operasi dan berita acara kejadian, perencana melakukan survey ke lapangan untuk mengetahui detail kerusakannya yang akan dipakai dalam pembuatan Rencana Anggaran Biaya (RAB). Kemudian Perencana mulai menyusun Perencanaan.

Perencanaan tersebut harus dilengkapi dengan RAB, Analisa Volume, Analisa Terinci Harga Satuan Pekerjaan, Spesifikasi Umum/Teknis, gambar, hasil inspeksi, foto dan 
brosur atau referensi lainnya apabila diperlukan dengan formulir Ijin Penggunaan Anggaran (IPA) yang telah ditetapkan. Kemudian Perencana melaporkan perencanaan tersebut kepada Kepala Sub Bagian Program Pemeliharaan melalui Juru Tata Usaha Pengolahan Data Pemeliharaan untuk dikonfirmasikan program kerja dan anggarannya serta pencatatannya.

Kepala Sub Bagian Program Pemeliharan memeriksa dan mengevaluasi perencanaan tindak lanjut tersebut. Apabila hasil evaluasi perencanaan tindak lanjut tersebut sesuai dengan kebutuhan lapangan atau program kerja dan anggarannya, perencanaan tindak lanjut tersebut dilaporkan kepada Kepala Bagian Pemeliharaan untuk mendapat persetujuan. Kepala Bagian Pemeliharaan memeriksa perencanaan tindak lanjut tersebut, dan apabila perencanaan tindak lanjut tersebut sesuai dengan kebutuhan lapangan atau program kerja dan anggarannya, maka Kepala Bagian Pemeliharaan mengusulkan perencanaan terebut kepada Kepala Cabang untuk meminta persetujuan melalui Bagian Keuangan untuk dikonfirmasikan anggaran dan program kerjanya.

Kepala Bagian Pemeliharaan menerima perencanaan tindak lanjut yang telah mendapat atau tidak mendapat persetujuan dari Kepala Cabang, selanjutnya Kepala Bagian Pemeliharaan mendisposisi perencanaan tersebut kepada Kepala Sub Bagian Program Pemeliharaan. Perencanaan tindak lanjut yang telah mendapat persetujuan Kepala Cabang kepada Sub Bagian Logistik untuk diproses pengadaan barang dan jasa melalui Juru Tata Usaha Pengolahan Data Pemeliharaan . Sedangkan bila anggaran yang diperlukan tidak tersedia, dan tidak mendapat persetujuan dari Kepala Cabang selanjutnya diserahkan kepada Juru Teknik dan Teknisi terkait untuk direvisi.

\subsection{Analisis Instruksi Kerja Pengendalian Mutu Pekerjaan}

Penanggung jawab dalam pelaksanaan instruksi kerja ini adalah Kepala Bagian Pemeliharaan. Petugas pengendalian mutu pekerjaan bertanggung jawab kepada Kepala Bagian Pemeliharaan. Setelah menerima surat penugasan dan SPK, Petugas pengendalian mutu pekerjaan melaksanakan pemeriksaan dan evaluasi terhadap dokumen kontrak sebelum pelaksanaan lapangan dimulai. Kemudian menyelenggarakan rapat pra pelaksanaan pekerjaan (Pre construction meeting) dan membahas kesepakatan kerja dengan pihak kontraktor sesuai dengan ketentuan kontrak yang telah disepakati.

Setelah melaporkan hasil rapat dan menerima kelengkapan administrasi kontraktor, petugas pengendalian mutu pekejaan harus melakukan pemeriksaan terhadap kelengkapan administrasi kontraktor tersebut sebelum pelaksanaan lapangan. Bila kelengkapan terpenuhi petugas meminta persetujuan Kepala Bagian Pemeliharaan untuk menerbitkan Surat Perintah 
Mulai Pelaksanaan (Work Order), serta persetujuan untuk menerbitkan Berita Acara Serah Terima Lapangan (Site Hand Over) melalui Kepala Bagian Pemeliharaan.

Setelah mendapatkan persetujuan Petugas pengendalian mutu pekerjaan dapat melaksanakan pemeriksaan terhadap material dan peralatan yang dipergunakan dilapangan, apakah sesuai dengan yang disyaratkan dalam kontrak. Yang nantinya hasil pemeriksaan fisik pekerjaan tersebut dituangkan ke dalam Berita Acara untuk diproses.

\section{KESIMPULAN DAN SARAN}

\subsection{Kesimpulan}

1. Dengan menggunakan Manajemen Pemeliharaan Jalan Tol akan memudahkan pelaksanaan pekerjaan pemeliharaan pada jalan tol.

2. Dari Struktur Organisasi Jalan Tol Padalarang-Cileunyi yang telah dipelajari, diperoleh struktur organisasi yang baik dan saling berkoordinasi dalam menjalankan tugas.

3. Berdasarkan tata cara pelaksanaan pekerjaan perbaikan jalan tol PadalarangCileunyi yang telah dipelajari, diperoleh Manajemen Pemeliharaan Jalan Tol yang baik.

\subsection{Saran}

1. Untuk penelitian lebih lanjut perlu dilakukan penelitian mengenai sumber daya manusia pada pekerjaan pemeliharaan jalan tol Padalarang-Cileunyi.

2. Untuk penelitian lebih lanjut perlu juga dilakukan penelitian mengenai biaya pemeliharaan jalan tol Padalarang-Cileunyi.

\section{DAFTAR PUSTAKA}

1. Cornelis, Renound. (2006), Prosedur Pemeliharaan Fasilitas Operasi, PT. Jasa Marga, Bandung.

2. Divisi Pelayanan Lalu Lintas dan Pemeliharaan. (1999), Kumpulan SK Direksi Tentang Pedoman Pemeliharaan Jalan Tol, PT. Jasa Marga, Bandung.

3. Divisi Pelayanan Lalu Lintas dan Pemeliharaan. (2000), Kumpulan SK Direksi Tentang Pedoman Pemeliharaan Jalan Tol, PT. Jasa Marga, Bandung.

4. Hudson, W, Ronald., Haas Ralph., Uddin, Waheed. (1997), Infrastructure Management, Mc Graw-Hill Book Company, New York. 
5. Mudjiyono. (2006), Identifikasi Kinerja Gerbang Tol Jalan Tol Padalarang Cileunyi, Departemen Teknik Sipil ITB, Bandung.

6. Nugroho, Mardi, Imam. (2005), Penetapan Prioritas Pemeliharaan Rutin dan Periodik Jalan di Sungailiat Kabupaten Bangka Menggunakan Metode Proses Hirarki Analitik (PHA), Universitas Sriwijaya, Palembang.

7. Winarsa, Dwi. (2006), Instruksi Kerja Inspeksi Sarana Fasilitas Operasi, PT. Jasa Marga, Bandung.

8. Winarsa, Dwi. (2006), Instruksi Kerja Pendataan Aset Sarana Fasilitas Operasi, PT. Jasa Marga, Bandung.

9. Winarsa, Dwi. (2006), Instruksi Kerja Pengendalian Mutu Pekerjaan, PT. Jasa Marga, Bandung.

10. Winarsa, Dwi. (2006), Instruksi Kerja Perencanaan Tindak Lanjut, PT. Jasa Marga, Bandung.

11. Wirawan, Adhi. (2005), Evaluasi Kinerja Pemeliharaan Rutin Jalan Tol Kota Semarang, Departemen Teknik Sipil ITB, Bandung.

[1] Maksum Tanubrata, Ir., MT., Dosen Tetap, Jurusan Teknik Sipil Universitas Kristen Maranatha.

[2] Dini Handayani Asmara, ST., Alumnus Jurusan Teknik Sipil Universitas Kristen Maranatha. 